\title{
Localization of proteasomes in plant cells
}

\author{
Ulrike Vallon and U. Kull* \\ Biologisches Institut, Universität Stuttgart, Stuttgart \\ Received March 11, 1994 \\ Accepted April 29, 1994
}

\begin{abstract}
Summary. Proteasomes, also known as multicatalytic proteinase complexes, were localized in suspension cells of potato (Solanum tuberosum) by direct immunofluorescence using polyclonal antibodies labelled with fluorescein isothiocyanate. The method used allows an estimate of relative amounts of proteasomal antigens in different cell components. Proteasomes are present in the nuclei and the cytoplasm. The nucleoplasm contains small areas of weak fluorescence. The peripheral cytoplasm and possibly elements of the cytoskeleton show higher fluorescence than other parts of the cytoplasm. This indicates a localization of proteasomes similar to that known from animal cells.
\end{abstract}

Keywords: Cytoskeleton; Immunofluorescence; Multicatalytic proteinase; Nucleus; Plant cell; Proteasome.

Abbreviations: DMSO dimethylsulfoxide; EGTA ethyleneglycol-bis( $\beta$-aminoethylether)- $\mathrm{N}, \mathrm{N}, \mathrm{N}^{\prime}, \mathrm{N}^{\prime}$-tetra acetic acid; FITC fluorescein isothiocyanate; PBS phosphate buffered saline; PIPES piperazine1,4-bis-(2-ethanesulfonic acid).

\section{Introduction}

Proteasomes, also known as multicatalytic proteinase complexes (MCP or MPC) and isolated under a variety of different names (prosomes, macropain, ingensin) constitute a major proteolytic system in cells (for reviews, see Orlowski 1990, Rivett 1993, Rivett and Knecht 1993). They are known from animal cells (Wilk and Orlowski 1983, Tanaka et al. 1986), yeast (Achstetter et al. 1984, Arrigo et al. 1987) and cells of higher plants (Kremp etal. 1986, Schliephacke et al. 1991, Skoda and Malek 1992, Ozaki et al. 1992). The plant cytoplasmic particles described by Shelton et al. (1970) are probably identical with proteasomes too. The par-

\footnotetext{
* Correspondence and reprints: Biologisches Institut der Universität Stuttgart, Pfaffenwaldring 57, D-70550 Stuttgart, Federal Republic of Germany.
}

ticles are evolutionarily highly conserved (Genschick et al. 1992, Rivett and Knecht 1993) with broadly similar properties irrespective of their source (Orlowski 1990, Rivett 1993).

Proteasomes from eukaryotes are cylindrical particles of $20-23 \mathrm{~S}$, about $700 \mathrm{kDa}$, composed of a set of at least 15 proteins with molecular weights of $19-35 \mathrm{kDa}$. Their proteolytic activities can be attributed to several catalytic components. Proteasomes associate with other proteins, which apparently modulate their function and therefore may be classified as regulatory factors necessary for in vivo activity (Driscoll et al. 1992, Hoffman et al. 1992, Li and Etlinger 1992). In association, a $26 \mathrm{~S}$ proteinase system is formed which degrades ubiquitinized proteins and probably participates in ubiquitin-independent protein degradation (Goldberg 1992, Hershko and Ciechanover 1992, RichterRuoff etal. 1992, Rivett 1993).

From yeast mutants we know that some proteasome subunits are essential for cell viability and growth, suggesting important functions in cellular protein turnover. Yeast mutants also allowed a function in stress induced proteolysis necessary for cell survival to be determined (Heinemeyer et al. 1991, Hilt et al. 1993).

Localization of proteasomes was investigated in various types of animal cells using different methods (reviewed in Rivett and Knecht 1993). The particles were found in the cytoplasm and nuclei of cells of vertebrates and invertebrates. The occurrence of particles, which we now know to be proteasomes, in the cytoplasm and nucleus of Xenopus was first described by Hügle et al. (1983). Allocation between the two compartments varies according to cell type (Haass et al. 1989) and further 
changes during development and the cell cycle (Rivett 1993).

Proteasomes have been identified in higher plants several times since 1986, but their cytolocalization was not observed. We describe the localization of proteasomes in cells of a suspension culture of Solanum tuberosum, revealed by direct immunofluorescence with polyclonal antibodies which allows an estimate of the relative amounts of proteasomal antigens in cellular compartments.

\section{Materials and methods}

Establishment of a cell suspension culture

A source callus culture from tuber cells of a dihaploid clone ( $\mathrm{HH} 258$ ) of Solanum tuberosum was grown at $23^{\circ} \mathrm{C}$ in the dark on LinsmaierSkoog medium "M 240" with 2,4-dichlorophenoxyacetic acid added according to Behnke (1975) and subcultured every three weeks. Cell suspension cultures were established after three weeks of growth by passing callus tissue through a screen to obtain small cell groups, which were cultivated with continuous shaking in the same medium without agar. The suspension culture was subcultured every 7 days. Starting with about $5 \mathrm{~g}$ (fresh-weight) callus tissue, $5-10 \mathrm{~g}$ of cells from the suspension culture were available every week. The yield was highest when suspension cells formed clusters of $3-6$ cells. When separating the callus through fine-mesh nets so that single cells prevailed in the suspension, their growth was much slower.

\section{Antibody isolation and loading with FITC}

Antibodies against potato proteasomes were raised in rabbits as described by Schliephacke etal. (1991). From the antiserum, the antibodies were isolated as described (Nowotny 1969) by precipitation with ammonium sulfate, centrifugation, suspending in phosphate buffer ( $\mathrm{pH} 7.4)$ and dialyzation against the buffer $\left(4^{\circ} \mathrm{C}\right)$. The antibodies were quickly frozen and stored at $-20^{\circ} \mathrm{C}$ until labelling took place.

For labelling with FITC, according to Clark and Shepard (1963), the antibodies were precipitated with ammonium sulfate, suspended in $\mathrm{Na}_{2} \mathrm{CO}_{3}$-buffer ( $\mathrm{pH} 9.9$ ), dialyzed $\left(24 \mathrm{~h}, 4^{\circ} \mathrm{C}\right.$ ) against this buffer and then against the FITC containing buffer $\left(24 \mathrm{~h}, 4^{\circ} \mathrm{C}\right)$. The obtained antibody-FITC conjugates were separated from free FITC by gelfiltration (Sephadex PD 10). As a control, immunoglobulins from a pre-immune rabbit serum were prepared by the same method.

\section{Immunofluorescence microscopy}

Cells of the suspension culture were harvested after six days by centrifugation and washed by resuspending in MS buffer $(0.1 \mathrm{M}$ PIPES, $\mathrm{pH} 6.9$, and $3 \mathrm{mM}$ EGTA). To obtain predominantly single cells the culture was passed through nylon-tissue (mesh width $100 \mu \mathrm{m})$. Cell fixation and incubation with FITC loaded antibodies was accomplished following Schroeder et al. (1985) and Iwasaki et al. (1988).

After washing with MS buffer cells were incubated for $60 \mathrm{~min}$ in a fixation and extraction medium containing formaldehyde $(3.7 \%, \mathrm{v} /$ v) as a fixative and DMSO (10\%) to stabilize the cytoskeletal network. This was necessary due to reports suggesting linkage between animal cell proteasomes and cytoskeleton elements (Grossi de Sa et al. 1988 b, Briane etal. 1992). After fixation the cells were washed three times for $10 \mathrm{~min}$ in MS buffer.

To achieve uniform permeabilization of the plasmalemma it is nec- essary to degrade the cell walls. To achieve this, cells were treated with enzyme solution (cellulase, pectinase) in MS buffer and then rinsed with MS buffer alone.

Carefully cleaned cover-slips were incubated in poly-L-lysine (Sigma) $(15 \mathrm{~min})$ and dried $\left(1 \mathrm{~h}, 60^{\circ} \mathrm{C}\right)$. Cells were allowed to settle on the cover-slips. To remove cellular components showing non-specific fluorescence, adhered protoplasts were incubated in MS buffer $\left(30 \mathrm{~min}, 27^{\circ} \mathrm{C}\right)$ containing $1 \%(\mathrm{w} / \mathrm{v})$ Triton $\mathrm{X}-100$ and $10 \%(\mathrm{v} / \mathrm{v})$ DMSO (Iwasaki et al. 1988). By this procedure, the plasmalemma was permeabilized for antibodies. After two rinses of the adhered protoplasts with MS buffer incubation with FITC loaded antibodies was accomplished $\left(60 \mathrm{~min}, 37^{\circ} \mathrm{C}\right)$. Superfluous free antibodies were removed by repeated careful rinsing with $0.05 \%$ Tween 20 in PBS. For microscopy, cells on the cover-slips were mounted in glycerol/ PBS $(1: 1)$ containing $0.1 \%$ phenylene diamine (Falconer and Seagull 1985). Immunofluorescence was observed with a Zeiss epifluorescence microscope and photographed on colour slide film (400 ASA). As a control, FITC loaded pre-immune serum was used in the same procedure.

\section{Results}

Cells incubated with FITC-labelled antibodies showed distinct fluorescence, not only in the cytoplasm but also

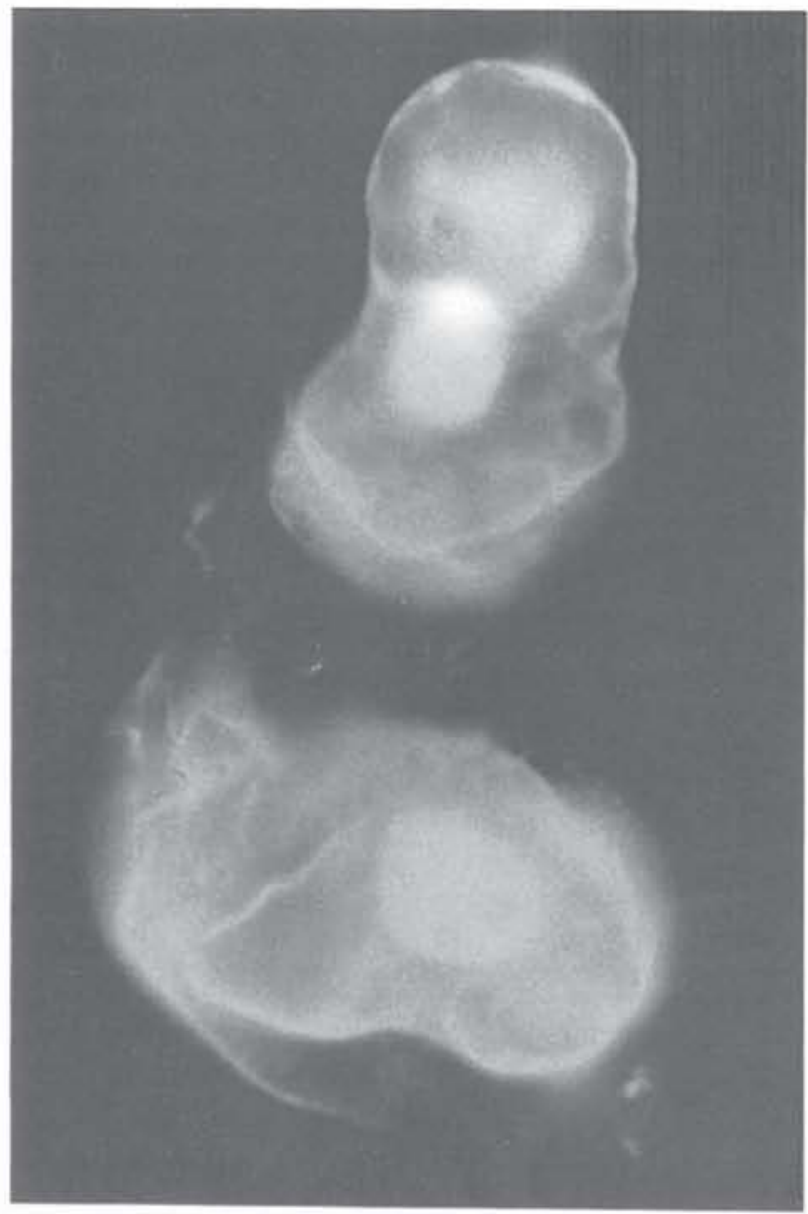

Fig. 1. Cytolocalization of proteasomal antigens in suspension cells of Solanum tuberosum after incubation with FITC labelled antibodies. $\times 650$ 
in the nuclei (Fig. 1). This indicates the presence of proteasomes in both cell compartments. In the controls, incubated with pre-immune serum, no fluorescence was observed. In many cases the peripheral area of the cytoplasm showed more intense fluorescence than other parts. However, in most cells fluorescence intensity was highest in the nuclei. The nucleoplasm contains small areas with very weak fluorescence; these are probably the nucleoli not containing proteasomal antigens. In some cases, in cells which have lost a portion of their cytoplasm during the permeabilization procedure, a network with a diverse fluorescence is observed in the cytoplasmatic space, which is perhaps formed by cytoskeletal elements. If this interpretation is correct, proteasomes may perhaps also be connected to the cytoskeleton of plant cells.

\section{Discussion}

In cells of a suspension culture of Solanum tuberosum proteasomes are localized in the cytoplasm and, in comparatively higher concentrations, in the nucleus. This cytolocalization, shown here for the first time for plant cells, is similar to findings for animal cells from several investigations, beginning with Hügle et al. (1983) and reviewed by Rivett (1993). The proportion of proteasomes in the cytoplasm compared to the nucleus varies with cell type (Haass etal. 1989) and changes during development (Arrigo et al. 1988, Grainger and Winkler 1989, and others). A similar distribution for particles, named prosomes, now known to be identical with proteasomes (Grainger and Winkler 1989, Nothwang et al. 1992), was detected independently by Martins de Sa et al. (1986) and Kloetzel et al. (1987), while Grossi de $\mathrm{Sa}$ et al. (1988 a) showed that their distribution is dependent on differentiation processes. Connection between the proteasomes and the cytoskeleton has been demonstrated in animal cells (Grossi de Sa etal. 1988 b). By immunofluorescence methods using monoclonal antibodies against three different proteasomal proteins these authors showed that the particles were associated with cytokeratin filaments. In addition they observed free proteasomes. Essentially similar results were obtained by Briane et al. (1992).

The rather high concentration of proteasomes which we observed near the cell periphery is similar to that sometimes found for animal cells. These findings were discussed by Rivett and Knecht (1993) who postulate that the metabolism of proteins of the cytoskeletal network and its anchorage in the membrane is regulated by proteasomes accumulated near the cell surface. Such a regulatory function is of great interest in relation to the cytoskeleton-cell wall continuum (Wyatt and Carpita 1993) in plants. Stress during cell separation may lead to the accumulation of proteasomes near the plasma membrane.

In many potato cells proteasome density was higher in the nucleus than in the cytoplasm. This is also true for many animal cells (reviewed in Rivett 1993). It is not surprising if the presumed substrates of proteasomal protein degradation in the nuclear compartment are considered. According to Rivett and Knecht (1993) these seem to be short-lived regulatory proteins, as, e.g., transcription factors. Our observations thus confirm conclusions drawn from proteasome distribution in animal cells. The important role of these particles in non-lysosomal protein degradation requires stringent control (Hershko and Ciechanover 1992) due to its significance comparable to that of regulation of protein synthesis, but not known yet.

\section{Acknowledgements}

For the gift of the potato callus culture we thank Dr. Ines Schindler, University of Hamburg; for correction of the English thanks are due to Carsten Hoffmann, and for typing of the manuscript to Sabine Pfafferott.

\section{References}

Achstetter T, Ehmann C, Osaki A, Wolf DH (1984) Proteolysis in eukaryotic cells. Proteinase ysc E, a new yeast peptidase. J Biol Chem 259: 13344-13348

Arrigo AP, Simon M, Darlix JP, Spahr PF (1987) A 20 S particle ubiquitous from yeast to human. J Mol Evol 25: 141-150

- Tanaka K, Goldberg AF, Welch WJ (1988) Identity of the 19S prosome particle with the large multifunctional protease complex of mammalian cells (the proteasome). Nature 331: 192-194

Behnke M (1975) Regeneration in Gewebekulturen einiger dihaploider Solanum tuberosum-Klone. Z Pflanzenzucht 75: 262-265

Briane D, Olink-Coux M, Vassy J, Oudar O, Huesca M, Scherrer K, Foucrier J (1992) Immunolocalization of a specific type of prosome close to the bile canaliculi in fetal and adult rat liver. Eur J Cell Biol 57: 30-39

Clark HF, Shepard CC (1963) A dialysis technique for preparing fluorescent antibody. Virology 20: 642-644

Driscoll J, Frydman J, Goldberg AL (1992) An ATP-stabilized inhibitor of the proteasome is a component of the $1500 \mathrm{kDa}$ ubiquitin conjugate-degrading complex. Proc Natl Acad Sci USA 89: 4986-4990

Falconer MM, Seagull RW (1985) Xylogenesis in tissue culture: taxol effects on microtubule reorientation and lateral association in differentiating cells. Protoplasma 128: 157-166

Genschik P, Philipps G, Gigot C, Fleck J (1992) Cloning and sequence analysis of a cDNA clone from Arabidopsis thaliana homologous to a proteasome subunit of Drosophila. FEBS Lett 309: $311-315$

Goldberg AL (1992) The mechanism and functions of ATP-de- 
pendent proteases in bacterial and animal cells. Eur J Biochem 203: 9-23

Grainger JL, Winkler MM (1989) The sea urchin multicatalytic protease: purification, biochemical analysis, subcellular distribution and relationship to snRNPs. J Cell Biol 109: 675-683

Grossi de Sa MF, Martins de Sa C, Harper F, Olink-Coux M, Akhayat O, Pal JK, Florentin Y, Scherrer K (1988 a) Cytolocalization of prosomes as a function of differentiation. $\mathrm{J}$ Cell Sci 89: $151-165$

- - - - Huesca M, Scherrer K (1988b) The association of prosomes with some of the intermediate filament networks of the animal cell. J Cell Biol 107: 1517-1530

Haass C, Pesold-Hurt B, Multhaup G, Beyreuther K, Kloetzel PM (1989) The Pros-35 gene encodes the $35 \mathrm{kd}$ protein subunit of Drosophila melanogaster proteasome. EMBO J 8: 2373-2379

Heinemeyer W, Kleinschmidt JA, Saidowsky J, Escher C, Wolf DH (1991) Proteinase yscE, the yeast proteasome/multicatalytic-multifunctional proteinase: mutants unravel its function in stress induced proteolysis and uncover its necessity for cell survival. EMBO J 10: 555-562

Hershko A, Ciechanover A (1992) The ubiquitin system for protein degradation. Annu Rev Biochem 61: 761-807

Hilt W, Enenkel C, Gruhler A, Singer T, Wolf DH (1993) The PRE4 gene codes for a subunit of the yeast proteasome necessary for peptidylglutamyl-peptide hydrolyzing activity. J Biol Chem 268: 3479-3486

Hoffmann L, Pratt G, Rechsteiner M (1992) Multiple forms of the $20 \mathrm{~S}$ multicatalytic and the $26 \mathrm{~S}$ ubiquitin/ATP-dependent proteases from rabbit reticulocyte lysate. J Biol Chem 267: 2236222368

Hügle B, Kleinschmidt JA, Franke WW (1983) The 22 S cylinder particles of Xenopus laevis II. Immunological characterization and localization of their proteins in tissues and cultured cells. Eur J Cell Biol 32: 157-163

Iwasaki T, Fukuda H, Shibaoka H (1988) Relationship between DNA synthesis and the increase in the level of tubulin during the differentiation of isolated Zinnia mesophyll cells. Protoplasma 143: 130-138

Kloetzel PM, Falkenburg PE, Hössl P, Glätzer KH (1987) The 19S ring type particles of Drosophila. Exp Cell Res 170: 204-213

Kremp A, Schliephacke M, Kull U, Schmid HP (1986) Prosomes exist in plant cells too. Exp Cell Res 166: 553-557

Li XS, Etlinger JD (1992) Ubiquitinated proteasome inhibitor is a component of the $26 \mathrm{~S}$ proteasome complex. Biochemistry 31 : 11963-11967

Martins de Sa C, Grossi de Sa M, Akhayat O, Broders F, Scherrer K (1986) Prosomes: ubiquity and interspecies structural variation. J Mol Biol 187: 479-493

Nothwang HG, Coux O, Bey F, Scherrer K (1992) Prosomes and their multicatalytic proteinase activity. Eur J Biochem 207: 621630

Nowotny A (1969) Basic exercises in immunochemistry. A laboratory manual. Springer, Berlin Heidelberg New York

Orlowski M (1990) The multicatalytic proteinase complex, a major extralysosomal proteolytic system. Biochemistry 29: 10289 10297

Ozaki M, Fujinami K, Tanaka K, Amemiya Y, Sato T, Ogura N, Nakagawa H (1992) Purification and initial characterization of the proteasome from the higher plant Spinacia oleracea. J Biol Chem 267: 21678-21684

Richter-Ruoff B, Heinemeyer W, Wolf DH (1992) The proteasome/ multicatalytic-multifunctional proteinase. In vivo function in the ubiquitin-dependent $\mathrm{N}$-end rule pathway of protein degradation in eukaryotes. FEBS Lett 302: 192-196

Rivett AJ (1993) Proteasomes: multicatalytic proteinase complexes. Biochem J 291: 1-10

- Knecht E (1993) Proteasome location. Curr Biol 3: 127-129

Schliephacke M, Kremp A, Schmid HP, Köhler K, Kull U (1991) Prosomes (proteasomes) of higher plants. Eur J Cell Biol 55: 114-121

Schroeder M, Wehland J, Weber K (1985) Immunofluorescence microscopy of microtubules in plant cells; stabilization by dimethylsulfoxide. Eur J Cell Biol 38: 211-218

Shelton E, Kuff, EL, Maxwell ES, Harrington JT (1970) Cytoplasmic particles and aminoacyl transferase I activity. J Cell Biol 45: 18

Skoda B, Malek L (1992) Dry pea seed proteasome. Purification and enzymatic activities. Plant Physiol 99: 1515-1519

Tanaka K, Ii K, Ichihara A, Waxman L, Goldberg AL (1986) A high molecular weight protease in the cytosol of rat liver I. Purification, enzymological properties, and tissue distribution. J Biol Chem 261: 15197-15263

Wilk S, Orlowski M (1983) Evidence that pituitary cation-sensitive neutral endopeptidase is a multi-catalytic protease complex. J Neurochem 40: 842-849

Wyatt SE, Carpita NC (1993) The plant cytoskeleton-cell-wall continuum. Trends Cell Biol 3: 413-417 